Journal of Development and Communication Studies, Vol. 8. No. 2, July -December, 2021 ISSN (Online \& Print): 2305-7432. http://www.devcomsjournalmw.org

\title{
Challenges associated with the delivery of development projects within the decentralised government system: views of selected stakeholders in the Shama District, Ghana
}

Daniel Odoom, Lecturer, Department of Communication Studies, Ghana Institute of Journalism, Ghana

Lawrencia Agyepong, Head of Department of Communication Studies, Ghana Institute of Journalism, Ghana. Email: agyeponglawrencia@gij.edu.gh; agyeponglawrencia@gmail.com

Francis Kojo Mensah, Managing Director, Abbtech Services, Takoradi, Ghana

Ernest Opoku, Development Researcher and PhD Candidate, University of Cape Coast, Ghana

Yaw Owusu Amoabeng, Regional Manager, Youth Employment Agency, Western Region, Ghana

\begin{abstract}
Decentralisation policy is important in ensuring effective delivery of development services at the local level. Governments across the globe utilize decentralised government system as a way of promoting people-centered development. Notwithstanding the value of decentralisation policy, governments struggle with the provision of development services at the local level. This suggests that more efforts need to be made to ensure the realisation of the dividends of decentralisation. However, this cannot be made without an awareness of the challenges local actors face in the delivery of development services. This paper examines the views of stakeholders on the challenges associated with the delivery of development projects within the Ghanaian decentralised government system using the Shama District as a case in order to proffer some measures to improve the situation in the country using the sequential-explanatory mixed method design. Data were collected using interview guide and interview schedule. The study revealed that stakeholder management, involvement of project managers, defining project goals, assigning roles and responsibilities to key officers, and monitoring and evaluation of projects were some of the measures the Assembly had put in place for the delivery of development projects in the district. However, communication was a serious challenge throughout the delivery of development projects in the district. The implications of the key findings for development communication have been highlighted in the study. As part of the recommendations of the study,
\end{abstract}


the Assembly should put in place adequate measures to improve communication throughout the various stages of development service delivery in the district.

Keywords: decentralised government, development projects, district assemblies, communication, development communication

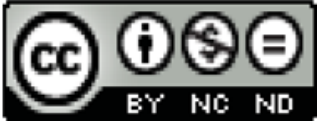

(C) 2021. The authors. This work is licensed under the Creative Commons Attribution 4.0 International License (CC-By-NC-ND). Users may freely share and redistribute this work provided that the author and the Journal of Development and Communication Studies are fully acknowledged. Users may not tweak or remix and offer this work for sale. The full license may be accessed at https://creativecommons.org/licenses/ by-nc-nd/4.0/

To cite this article: Odoom, D., Agyepong, L., Mensah, F.K., Opoku, E., \& Amoabeng, Y.O, (2021), Challenges associated with the delivery of development projects within the decentralised government system: views of selected stakeholders in the Shama District, Ghana, Journal of Development and Communication Studies, 8(2), 37-57. https://dx.doi.org/10.4314/jdcs.v8i2.3

\section{Introduction}

Development is a dynamic process which empowers and promotes important changes in the lives of people (Opoku, Kyeremeh \& Odoom, 2014). Development thrives on an educated population, physical and financial resources. In order to ensure improvement in the lives of their citizenry, governments all over the world have initiated various development approaches over the past decades. Decentralisation has become one vital approach which helps to improve local governance and delivery of effective public service by increasing 'allocative' and 'productive' efficiency (World Bank, cited in Odoom, Kyeremeh \& Opoku, 2014). As a policy, decentralisation gains relevance on the basis that a positive correlation exists between governance and citizens' wellbeing when functions and powers, skills and competencies, as well as the means and resources are transferred from the central government to the lowest levels of governance (Ahwoi, 2006; Gyabaah, 2006).

Cheema, as cited in Odoom (2016), submits that the basics of decentralisation are the transfer of authority for decision making, planning, management or resource allocation from the central government to the local government. Agrawal and Ribot, as cited in Odoom (2016), view decentralisation as an action by which the central government officially cedes power to actors and institutions at lower levels in a political-administrative and territorial hierarchy. Indeed, decentralised government system has become the most current and dramatic fashion in the social and political sciences (Campbell, 2001; Conyers, 1983). In an attempt to provide justification to the policy, Diamond (1999) maintains that the recent wave of decentralisation has been 
provoked by a variety of pressures including urbanisation, democratic transition, shifts in international donors and societal demands. In particular, the international community and donors see decentralisation as a commendable tool to consolidate democracy (Grindle, 2007; Lederach, 1997; Manor, 2011). As a development approach, decentralisation is about devolving administrative, political, and financial responsibilities to sub-national governments to deliver improved public services to the people in an efficient and accountable manner (Stigler, cited in Odoom, Mensah, Opoku \& Acheampong, 2018).

The decentralised system of government in Ghana had its legal backing by the Local Government Law 1988, Provisional National Defense Council Law (PNDCL) 207. Subsequent to the efforts at reforming the country's public sector, the Local Government Act, 1993, Act 462 was amended in Chapter 20 of the 1992 Constitution. In order to ensure effective decentralisation, the Ministry of Local Government and Rural Development (MLGRD) embarked on a District Resourcing Program in 1992 under the ministry's three-year rolling Public Investment Program (PIP) aimed at providing accommodation and other logistics to the 45 newly created districts in the year 1988 (Odoom et al., 2014; World Bank, 2000).

As part of Ghana's fiscal decentralisation strategies, the various Metropolitan, Municipal and District Assemblies (MMDAs) are expected to generate revenue locally to undertake their development projects. In line with the fiscal decentralisation framework, each public service is expected to be provided by the jurisdiction having control over the minimum geographic area that would internalize benefits and costs of such services (Opoku et al., 2014). The aim is to provide adequate financial capacity for the local governments (LGs) to have enough resources in order to deliver meaningful services that improve the lives of the people (Ebel \& Yilanmaz, 2001; Opoku et al., 2014). In the estimation of Tettey (2006), the District Assemblies (DAs) are expected to identify revenue structures which can provide sufficient financial resources necessary for effective local service delivery. In line with their mandates, the DAs provide development services such as schools, market centers, clinics, hospitals, roads, pipeborne water and toilets to improve the lives of inhabitants in their localities (Asibuo, 2000; Atakora, 2006).

In spite of the legal backing given to the MMDAs in Ghana to undertake development services within their jurisdictions, the rate of development in many parts of the country is low. In a study conducted by Atakora (2006), it was observed that the rate of development in the Nkoranza District is low. Similarly, Egbenya, as cited in Opoku et al. (2014), found that there is low rate of development in Abura-AsebuKwamankese District despite the mandate given to the DA to undertake development services. Thus, many Assemblies are faced with diverse challenges with respect to the delivery of development services to improve the lives of their citizens. What is more, it is widely recognised that development projects undertaken in Ghana fail to meet the expectations of the people (Atakora, 2006; Damian, 2012). 
There is a growing acceptance of the fact that issues such as delays in completion of development projects, poor execution of development projects, as well as inappropriate location of projects exacerbate the seemingly appalling rates of development service provision within the decentralised government system (Damian, 2012). On their part, Shava and Thakhathi (2017) identified factors such as skills shortage, corruption, poor infrastructure, poor monitoring and evaluation as impeding the effective management of development projects. These challenges tend to hamper smooth delivery of development services which ultimately disrupts the noble intention of decentralisation. Particularly, the challenges associated with the delivery of development services have implications for development communication especially in the country. As a practice, development communication focuses on the systematic use of communication channels, methods and strategies to promote social change and development. In order to achieve sustainable development services, there must be mechanisms to promote broad participation by all stakeholders. Thus, the continuing existence of development challenges at the local level of Ghana suggests a seeming lack of appreciation and application of development communication. Needless to suggest that the need to bring all development actors onboard in the interest of promoting sustainable development services at the local level as espoused by development communication cannot be gainsaid (Mefalopulos, 2008; Odoom, 2020).

In essence, all stakeholders including the DAs, community members and opinion leaders have an enormous to put in place adequate measures to make the decentralised government system a success. Achieving this, however, requires a full understanding of the challenges the DAs face regarding the delivery of development services. This also means that more studies need to be conducted to bring to light the various challenges DAs face in the delivery of development services. Against this background, this study aimed at analysing the views of selected stakeholders regarding the challenges associated with the delivery of development services in Ghana using Shama District as a case in order to proffer measures for improvement. Though the Shama District Assembly had provided diverse development projects in the district, this study focused on projects in the areas of education, health, roads, market centers, water and sanitation. Again, the study discusses the implications the prevailing situation in the district presents for development communication practice generally in Ghana.

\section{Research Objectives}

The study specifically sought to:

1. Examine the views of stakeholders on the measures the Assembly has put in place for the delivery of development projects in the district.

2. Explore the challenges the Assembly is faced with in the delivery of development projects in the district.

3. Determine whether or not differences exist in the views of male and female stakeholders in the delivery of development projects in the district. 


\section{Methodology}

The sequential-explanatory mixed method design was adopted in this study. Sequential-dependence design occurs in instances where the data collection for one approach precedes the other approach but the data analysis of one approach will depend on the other approach (Guest, 2013). In other words, the sequential-dependence mixed methods design involves the collection and analysis of one data (be it quantitative or qualitative data) followed by the collection and analysis of another data (be it quantitative or qualitative data). Sequential-dependence mixed methods design can be explanatory or exploratory. When priority is given to the quantitative data, and the findings are interpreted during the interpretation phase of the study, then the design is called sequential explanatory design. In this study, emphasis was placed on the quantitative data (Schoonenboom \& Johnson, 2017). Purposive, convenience sampling and census data collection techniques were used to select 91 respondents from a population made up of the Planning Officer, Budget Analyst, Coordinating Director, Deputy Directors, Engineer, and the Head of Works Department. Others are the Assembly members, Unit Committee members, PTA Executives, SMC Executives, market women, representatives of traditional authority, and members from the Executive Committee. Purposive sampling technique was used to select the key officers at the District Assembly namely, Coordinating Director, Deputy Coordinating Directors, Planning Officer, Budget Analyst, Engineer, and the Head of Works Department. These officers play a crucial role in the planning and execution of projects in areas including education, health, roads, water and sanitation.in the district. The Coordinating Director, Deputy Directors, Planning Officer, Budget Analyst, Head of Environmental Health Department, Engineer, and the Head of Works Department were involved in this study due to their role in the provision of educational, health, roads, water and sanitation projects at the Assembly.

All the 17 Assembly members in the district were involved in the study using census data collection method. The Assembly members are the representatives of the people at the District Assembly level. The Assembly members also play an important role in the planning and management of projects in communities in their various electoral areas. Again, convenience sampling method was used to select 10 Unit Committee members, 14 Parent Teachers' Association Chairpersons, 14 School Management Committee Chairpersons, 12 market women, eight representatives of traditional authority, four members from the Executive Committee, and four members from sub-committees of the Assembly.

Many researchers prefer convenience sampling method because it is fast, inexpensive, easy and the subjects are readily available (Babbie, 2004; Sarantakos, 2005). These officers are key representatives of communities in the district. For instance, PTA Executives and SMC executives play a critical role in mobilising community members to support the provision of educational projects in the communities. The Assembly members, Unit Committee members and traditional authorities are also an important 
part of the leadership set-ups in the various communities whose roles are key in the provision of all development projects. Their inputs are, therefore, vital in the development process especially at the local level. A total of 91 key stakeholders were involved in the study.

Primary data was collected with the use of interview guide and interview schedule. A set of interview guides was conducted on the Coordinating Director and the two Deputy Coordinating Directors. Also, a set of interview schedules was conducted on the remaining respondents made up of the Planning Officer, Budget Analyst, Engineer, the Head of Works Department, and the Assembly members. Others were Unit Committee members, PTA Executives, SMC Executives, representatives of traditional authority, members from the Executive Committee, and members from subcommittees of the Assembly. Out of the 91 respondents selected, 88 responded to the interview schedule whilst three underwent the interview guide. Data was collected on the measures the Assembly has put in place to manage its development projects in the district. Data was also gathered in respect of the challenges the Assembly is faced with in the delivery of development projects in the district. Quantitative tools such as frequencies, percentages, means, standard deviation and Mann-Whitney $U$ text were used to analyze the quantitative data whereas for the quantitative analysis, thematic analysis was done based on the transcribed data.

\section{Results and Discussion}

This section presents the results and discussion of the study in two parts. The first part captures the demographic features of the respondents, whilst the second part considers the results based on the research objectives. One demographic feature identified in this study is the sex distribution of respondents. With respect to sex, the study found that 54.5 percent of the respondents were males whilst 45.5 percent were females. This means that most (54.5per cent) of the respondents were males. Knowledge of sex composition influences the provision of development services (Mphande, 2016). The study again looked at the age of respondents. Bird and Smart, as cited in Opoku et al. (2014) contend that that differences in demographic features like sex have implications for local development. Specifically, the authors posit that, demographic features such as sex have effects on the capacity of local revenue mobilisation options. Also, Table 1 depicts that 12.5 percent of the respondents were between the ages of 25 and 29 years whiles 14.8 percent aged between 30 and 34 years. Besides, 34 percent of them had ages between 35 and 39 years whereas 20.5 percent were between 40 and 44 years. This suggests that many (61.3per cent) of the respondents had ages between 25 and 39 years. An awareness of age differences of a given population promotes local development. For example, differences in age of the citizens influence local governments' local revenue mobilisation plans and strategies (Solé-Ollé, 2006). 
Table 1: Age Distribution of Respondents

\begin{tabular}{lll}
\hline Age & Frequency & Percentage \\
\hline $25-29$ & 11 & 12.5 \\
$30-34$ & 13 & 14.8 \\
$35-39$ & 30 & 34.0 \\
$40-44$ & 18 & 20.5 \\
Above 44 & 16 & 18.2 \\
\hline Total & 88 & 100 \\
\hline
\end{tabular}

Again, Table 2 shows that 52.3 percent of the respondents had married followed by 27.3 percent who were single.

Table 2: Marital Status of Respondents

\begin{tabular}{lll}
\hline Status & Frequency & Percentage \\
\hline Single & 24 & 27.3 \\
Married & 46 & 52.3 \\
Divorced & 12 & 13.6 \\
Widowed & 6 & 6.8 \\
\hline Total & 88 & 100 \\
\hline
\end{tabular}

This means that more than half (52.3\%) of the key stakeholders who were involved in this study were married. Knowledge of people's marital status is key in any efficient development process. Scholars such as Alesina, Ichino and Karabarbounis (2010) opine that married people, especially females, should be made to pay lower rates of tax due to the enormous duties they bear.

\section{Measures the Assembly has put in place to ensure the Delivery of Development Projects \\ The first objective of the study examined the views of respondents on the measures the Assembly had put in place for the delivery of development projects in the district. Table 3 shows that stakeholder consultation prior to the delivery of projects was very low $(\mathrm{M}=$}


2.043, $\mathrm{SD}=1.618)$. Interviews with key informants revealed that even though stakeholders were engaged prior to the planning of projects in the district, their overall participation was low. In the words of one informant, "The Assembly involves various stakeholders before the execution of any development project. Sometimes, the Assembly has to depend on representatives of the stakeholders which becomes challenging especially if the representatives are not very committed to the task." The informants admitted that ineffective stakeholder engagement could hinder effective decentralisation and participatory development. This finding is similar to that of Ahenkan, Bawole and Domfer (2013) who discovered that poor stakeholder participation hampers the promotion of effective and responsible local governance. The situation at Shama District is very problematic according to Davis (2014) who opines that stakeholder participation is very important in the successful delivery of development projects and thus, requires increased attention at all levels.

Also, with mean scores of 3.214 and 3.351 respectively the respondents agreed that efforts to define and communicate project goals were low. Again, with mean scores of 2.052 and 2.330 the respondents respectively believed that project managers were not in full control of development projects they executed in the district and also the managers did not take timely decisions. On their part, the informants stated that project goals were defined and communicated to the key stakeholders such as the intended beneficiaries. One informant said, "The Assembly defines project goals and communicates them to key stakeholders." Another informant said, "The process to define project goals is participatory since the views of key stakeholders are solicited. We also communicate these goals to the stakeholders." However, the informants could not really tell whether representatives of the stakeholders solicited their views of their constituents before attending meetings to define project goals.

Table 3: Views of respondents on the measures the Assembly has put in place for the delivery of development projects in the district.

\begin{tabular}{lcc}
\hline Statement & Mean & Std. Dev. \\
\hline $\begin{array}{l}\text { Stakeholder consultation took place prior to the delivery of the } \\
\text { projects }\end{array}$ & 2.043 & 1.618 \\
There were clearly defined projects goals & 3.214 & 0.713 \\
$\begin{array}{l}\text { Projects goals were properly communicated to all the stakeholders } \\
\text { The Assembly had project managers for its projects }\end{array}$ & 3.351 & 0.163 \\
The Assembly had project managers who were in full control of its & 2.052 & 0.500 \\
projects & & \\
$\begin{array}{l}\text { Project managers took timely decisions } \\
\text { Stakeholders showed full commitment towards development }\end{array}$ & 3.131 & 1.733 \\
projects & & \\
$\begin{array}{l}\text { Community members were actively part of the planning of } \\
\text { development projects }\end{array}$ & 1.001 & 1.723 \\
$\begin{array}{l}\text { The Assembly had effective project teams for the management of } \\
\text { projects }\end{array}$ & 2.032 & 0.148
\end{tabular}


Community members were involved in the sod-cutting of projects

The Assembly assigned competent people to undertake the various project tasks

Clear roles and responsibilities were defined for team members of the projects

Formal training was provided to people who lacked the requisite skills

Regular meetings were held with all the stakeholders during the delivery of projects

Progress of the projects was monitored and communicated

The Assembly ensured that reports were given at the various stages of the projects

Unexpected crises and problems were properly identified and dealt with

Occasional changes were made in the delivery of the projects

Projects were evaluated against the set goals

Means were calculated based on a scale of: 1=Neutral, 2=Very Lowly Agree, 3=Lowly Agree, 4=Strongly Agree, 5=Very Strongly Agree

Moreover, the informants were not sure whether key decisions on project goals actually reached the various stakeholders such as community members and whether the representatives communicated the decisions to the people they represented on time. Generally, there is no clarity as to the kind of communication provided during the delivery of development services in the district. Designing clear communication measures among stakeholders during the delivery of educational, health, roads, market centers, water, and sanitation projects is vital in effective development process. Clear communication and consultation among stakeholders promote successful delivery of development projects (Davis, 2014). The inability of the informants to tell whether key decisions were communicated to all the multi-stakeholders leaves much to be desired based on the position of Hilhorst and Guijt (2006). The authors submit that to ensure effective delivery of development projects there is the need for proper stakeholder management process. However, Hilhorst and Guijt (2006) lament that multistakeholder process is subject to elite capture which limits active participation of marginalised stakeholders.

Moreover, the study found commitment of stakeholders towards development projects $(\mathrm{M}=3.131)$ as problematic, coupled with the fact that community members were not fully involved in planning development projects $(\mathrm{M}=1.001)$ in the district. Further, teams in charge of the management of development projects were perceived as not very effective (M=2.032). Also, the competence of people who were assigned to undertake the various tasks was generally perceived as low $(M=3.413)$. The results from the interview guide showed that indeed the commitment of major stakeholders was a problem. One informant remarked, "Due to delays in the release of funds from central 
government the Assembly sometimes finds it very difficult to get contractors to continue with projects they have started." Again, an informant stated, "Local revenue generated in the district is generally low. Sometimes certain development projects are abandoned due to inadequate funds." It was added that financial commitment from stakeholders such as community members is very poor which hampers development services." The interviewees also admitted that low involvement of community members in the planning of projects impedes commitment towards development service delivery.

Again, on the issue of competence of people assigned to undertake the various tasks the key informants believed that it was not a major issue. One interviewee said, "The Assembly did its best to select persons with the requisite skills to undertake the projects." Another interviewee remarked, "Well I believe we have always picked persons with the required expertise to execute projects in the district." In effect, commitment of stakeholders towards the various projects was problematic, coupled with the fact that community members were not fully involved in the planning of the projects. Again, from the findings it is clear that project teams for the various projects undertaken were not very effective, and that the competence of people assigned to undertake the various tasks was perceived as low. Community members' involvement and engagement are key in effective delivery of development projects (Pinto \& Slevin, 1987). Besides, according to the UNDP (2009), to ensure community ownership of development projects all the various stakeholders including men and women should be involved in the planning process.

Additionally, the study showed that the Assembly had project managers for the various projects they undertook $(\mathrm{M}=4.434, \mathrm{SD}=0.500)$. Community members were also always involved in the sod-cutting of development projects $(\mathrm{M}=4.013, \mathrm{SD}=0.501)$, coupled with the fact that occasional changes were made in the delivery of projects $(\mathrm{M}=4.323, \mathrm{SD}=0.332)$. The results from the interview guide were similar to the views expressed in the interview schedule. The interview guide showed "the Assembly had project managers in charge of projects they undertook", and that "community members are often invited to be part of the sod-cutting ceremonies." The interview guide also proved that in the course of executing projects some changes were occasionally made to some aspects of the projects. For example, sometimes the Assembly might have planned to construct a simple three classroom block for a community but would end up building urinals and other facilities for the school which were not part of the original plan.

Other issues which the researchers explored include whether or not regular meetings were held with all the stakeholders, progress of the projects was monitored and communicated, reports were given at the various stages of the projects, unexpected crises and problems were properly identified and dealt with, and whether or not projects were evaluated against their set goals. The results for these issues were not very encouraging (Table 3). For example, with a mean score of 3.331 the respondents lowly agreed that regular meetings were held with all the stakeholders. Again, the 
respondents lowly agreed $(\mathrm{M}=3.110)$ that project reports on the various stages of development projects were given to the various stakeholders in the district. During the interview session, the respondents indicated that the Assembly could not have regular meetings with all its stakeholders. However, the informants rejected the position that progress of the projects was not well monitored and communicated to stakeholders. The informants added that reports were given at the various stages of the projects but conceded that it was not frequent and very thorough.

\section{Challenges faced by the Assembly in the Delivery of Development Projects}

The second study objective dealt with the challenges the Assembly was facing in delivering development projects in the district. Table 4 shows the results from the interview schedule.

Table 4: Views of respondents on the challenges faced by the Assembly in the delivery of development projects.

\begin{tabular}{|c|c|c|}
\hline Challenge & Mean & Std. Dev. \\
\hline There was ineffective stakeholder management & 5.331 & 0.027 \\
\hline The cost of projects undertaken by the Assembly was high & 5.012 & 0.557 \\
\hline The timing of projects was poor & 5.135 & 0.562 \\
\hline $\begin{array}{l}\text { Communication between project contractors and the } \\
\text { Assembly was poor }\end{array}$ & 5.453 & 0.624 \\
\hline There was poor monitoring and evaluation of projects & 5.163 & 0.411 \\
\hline The quality of some projects was low & 5.233 & 0.521 \\
\hline $\begin{array}{l}\text { There were inadequate qualified personnel to monitor } \\
\text { projects }\end{array}$ & 5.058 & 0.474 \\
\hline There was too much delay in completion of many projects & 5.400 & 0.010 \\
\hline There were inadequate funds for executing projects & 5.453 & 0.624 \\
\hline Inadequate logistics for executing projects & 5.134 & 0.621 \\
\hline Low technology to aid the implementation of projects & 5.163 & 0.538 \\
\hline $\begin{array}{l}\text { There was corruption associated with the provision of } \\
\text { projects }\end{array}$ & 5.234 & 0.456 \\
\hline
\end{tabular}

Means were calculated based on a scale of: 1=Neutral, 2=Very Lowly Agreed, 3=Lowly Agree, 4-Moderately Agree 5=Highly Agree, 6=Very Highly Agree

The researchers discovered that managing stakeholders was a challenge to the delivery of development projects in the district $(\mathrm{M}=5.331, \mathrm{SD}=0.027)$. This implies that, despite its importance, stakeholder management constitutes a big challenge to the effective 
local development in the district. On their part, the key informants said that there were challenges with the management of some stakeholders which hamper the delivery of development services. One informant said, "For example, you cannot execute educational projects without involving school authorities and parents. However, some time it is very difficult to get parents to attend meetings to take critical decisions." When asked whether such decisions cannot be taken upon consultation with PTA and SMC executives, the informants said that sometimes it is very important to get the inputs of parents and teachers themselves before executing certain decisions. Another informant stated, "Market women find it very difficult to attend meetings even when such meetings are meant to address their own needs." However, the informants admitted that unfavorable timing, low education and apathy on the part of some stakeholders hinder effective stakeholder engagement towards the delivery of development projects in the district. The results from both approaches generally suggest that there are concerns with the management of stakeholders in the district.

Also, with a mean score of 5.012 and standard deviation of 0.557 the respondents believed that high cost of undertaking development projects was one major challenge the Assembly was faced with. In other words, the respondents highly agreed to the contention that high cost of projects constituted a challenge to the delivery of educational, health, roads, water and sanitation projects in the Shama District (Table 4). A similar view was expressed during the key informant interviews. The key informants agreed, "The cost of projects keeps increasing which is a major challenge to the effective delivery of development projects." The informants believed that costs of projects are often high due to the rising interest rates and the volatile economic environment. However, they said that the situation is not peculiar to the district. The findings mirror that of Odoom et al. (2018) who established that economic factors influence the management of development projects in Ghana.

Again, the respondents highly agreed that poor communication between project contractors and the Assembly was a challenge to the effective management of educational, health, roads, water and sanitation projects in the Shama District $(M=5.453$, $\mathrm{SD}=0.624)$. Interviews with the key informants showed that communication between project contractors and the Assembly was not very effective. The informants bemoaned that there were times project contractors would abandon certain projects they had been contracted to deliver without officially informing the Assembly. In the words of one interviewee, "The issue is even serious when the Assembly owes them. They will just abandon the projects without telling us anything. But this is a general issue in Ghana."

Moreover, the respondents mentioned low quality of some projects as another challenge the Assembly was faced with $(\mathrm{M}=5.233, \mathrm{SD}=0.521)$. The results from the interview guide showed that the Assembly was sometimes not pleased with the quality of projects delivered in the district. It was observed that in most cases when project contractors see that they were not getting the needed cooperation from the Assembly in terms of timely release of funds, they tend to do shoddy work. An interviewee said, "They won't care about the quality of the work especially if the Assembly fails to release 
the needed funds." Indeed, the issue of low quality of development projects raises questions about the effectiveness of decentralisation policies. As a policy, decentralisation is expected to ensure quality development services at the local level. Gyabaah (2006) maintains that the effectiveness of decentralisation must be understood in terms of the response the policy has to people's needs and priorities; and the capacity it has in meeting a variety of social, economic and political needs. Again, the findings present a big challenge to the practical relevance of the principle of subsidiarity which theoretically underpins decentralisation policies (Manor, 2011; Odoom et al., 2014).

More so, the study discovered that there was too much delay in the completion of educational, health, roads, water and sanitation projects initiated by the Assembly $(\mathrm{M}=5.400, \mathrm{SD}=0.010)$. This was the greatest challenge faced by the Assembly in the delivery of development projects in the district. This was affirmed by key informant interviews as one informant remarked, "Though Nyankrom road construction has been given contractors a couple of years ago the road has not been constructed. I admit the delay in constructing that road is unbearable." Another informant said, "Apemainyim road project has also taken many years to be completed." The informants conceded that though contracts have been given for the construction of other road projects, health centers and toilet facilities in the district by successive governments not many of them have been completed. They mentioned further that construction of refuse dump sites and pipe-borne water in some communities in the district has also witnessed unnecessary delays. In essence, the informants agreed that many of the projects initiated by the Assembly usually take a long time for them to be executed. They added that often political reasons contribute to the delays especially when there is a change of government. Other reasons include low local revenue generation, low community support, poor planning and poor monitoring.

This study mirrors that of Damian (2012) who found that delays in completion of development projects is a major challenge faced by MMDAs in Ghana. However, the gap in Damian's (2012) study appears to be his inability to adduce clear reasons for such occurrence. Regardless, the situation in the Shama District raises a serious concern about the effectiveness of Ghana's decentralisation policy. Implicit in decentralisation policy is the conviction that there will be efficient delivery of development services. Thus, decentralisation is expected to curb challenges associated with centralised system of government including delays in delivery of development services at the local level (Hutchcroft, 2001; Ribot, 2002; 2004).

Furthermore, inadequate funds $(\mathrm{M}=5.453, \mathrm{SD}=0.624)$ was identified to be a crucial factor undermining the effective delivery of development projects in the district. The results from the interview guide also corroborated the views expressed in the quantitative study. In essence, the respondents believed that the Assembly does not have the needed financial capacity to ensure effective provision of development services for the betterment of the citizens. This result is in line with a study conducted by Egbenya (2010) which found that inadequate funds is a major factor responsible for low level of development in the Abura-Asebu-Kwamankese District. The issue of 
inadequate funds to undertake development projects in the district is a challenge to the effectiveness of the fiscal decentralisation theory. Inherent in the theory is the conviction that by allowing lower levels of government to raise revenue at the local level they will be able to undertake development services in their jurisdiction (Faquet, cited in Odoom, 2016). According to Stanton (2009), the justification for extensive fiscal autonomy is that local government services would become more efficient if they were paid for by local taxes and fees. In places such as Switzerland, greater local government fiscal autonomy has led to faster economic growth (Martínez-Vázquez, 2011; Odoom, 2016). Martínez-Vázquez (2011), Odoom (2016) and Falleti (2005) believe that a vital indicator of fiscal decentralisation is the share of local government expenditures and revenues and their utility value within a clearly defined locality. More so, the situation in Shama District finds expression in the writings of Shava and Thakhathi (2017) who opined that, inadequate funds hamper the management of development projects.

Besides, inadequate qualified personnel, and poor logistics were identified as constituting a challenge to the effectiveness of development service provision in the district. In other words, the respondents stated that the Assembly did not have adequate well-qualified personnel for monitoring the execution of development projects coupled with the poor logistics the Assembly had. Similarly, the results from the interview guide indicated that the Assembly did not have enough well-qualified personnel to be in charge of the monitoring and evaluation of its various projects in the district. The key informants also had concerns with the kind of logistics the Assembly had to ensure the monitoring and evaluation of the various development projects undertaken in the district. These findings are consistent with Shava and Thakhathi (2017) who discovered that challenges such as skills shortage impede the management of development projects. Besides, the findings on inadequate personnel at the Assembly coincide with Odoom, et al. (2014) who discovered that District Assemblies in Ghana including Assin South do not have adequate qualified personnel for the delivery of their mandates. In the same vein, Odoom (2019) found that assemblies such as the Cape Coast Metropolitan Assembly did not have adequate and well-qualified personnel to fully perform the functions entrusted to them. In their attempt to explain the prevailing situation in Ghana, Hoffman and Metzroth (2010) contend that factors including poor social amenities especially in rural areas hinder the DAs' efforts to attract and retain well-qualified personnel for effective decentralisation. Ahwoi (2010) and Koranteng (2006) are of the belief that for the MMDAs in Ghana to effectively perform their responsibilities, there is the need for them to have an appropriate human resource capacity.

Nonetheless, corruption was enumerated as one challenge faced in the management of development projects in the district $(M=5.234)$. Although the key informants did not discount the fact that corruption may exist regarding the processes leading to the provision of development projects in the district, they did not consider it as a major issue hindering the district. The informants believed that corruption was not peculiar to the district. One informant remarked, "Corruption is common everywhere 
in the country which requires serious attention. Certain development projects may be poorly delivered due to perceived politics and corrupt practices involving the award of contracts. Well, these are perceptions which are common in Ghana." By implication, though the informants admitted that corruption may seem to be a challenge they felt the situation is not peculiar to the Assembly. They believed corruption is very common in Ghana especially with respect to the award of contracts. However, they seemed to belittle the potential effects of corruption on the delivery of development services in the case of the district. Further, the informants were of the belief that addressing corruption requires a national solution due to its systemic nature.

Indeed, despite the slight difference in the quantitative and qualitative responses, it is clear that possible cases of corruption appear to affect the delivery of development services in the district. The danger in the prevailing situation in the district has been outlined by Ayittey (2007) who argued that corruption is a threat to development in Africa. What is more, the systemic nature of corruption in Ghana, as perceived by the key informants, helps to deepen Ayittey's (2007) worry that corruption is one huge challenge most African nation face in their development strides.

Other issues such as poor monitoring and evaluation of projects, low technology, and the timing of projects were identified as posing a challenge to the effective management of development projects. The views of the key informants were not very different from the ones expressed in Table 4 with respect to monitoring and evaluation of projects, availability of technology, attention given to planning and the timing of development projects in the district. The findings on monitoring and evaluation are at variance with the calls by the UNDP (2009) which show that effective ownership of development projects requires improved participation monitoring and evaluation by various stakeholders. Hilhorst and Guijt (2003) contend that monitoring and evaluation processes have become problematic at the local level due to inadequate stakeholder involvement. Also, the problem with inadequate technology in the Assembly has been highlighted by Darison (2011), as cited in Opoku et al. (2014). The introduction of technology will greatly decrease the number of human errors in revenue generation at the assemblies (Darison, 2011).

Differences in the Views of Male and Female Respondents on Challenges the Assembly faces in the Delivery of Development Projects in the District

The final research objective sought to determine whether or not there are differences in the views of male and female respondents on the challenges the Assembly is faced with in the delivery of development projects in the district at 0.05 significance level (Table 5).

Table 5: A Mann-Whitney U-test analysis of the views of male and female respondents on the challenges the Assembly faces in the delivery of development projects in the district 


\begin{tabular}{|c|c|c|c|c|c|c|c|}
\hline Sex & $\mathrm{N}$ & $\begin{array}{l}\text { Mean } \\
\text { Rank }\end{array}$ & $\begin{array}{l}\text { Sum of } \\
\text { Ranks }\end{array}$ & $\begin{array}{c}\text { Mann- } \\
\text { Whitney U }\end{array}$ & $\begin{array}{c}\text { Wilcoxon } \\
\text { W }\end{array}$ & Z & Sig. (2-tailed) \\
\hline Males & 48 & 39.91 & 1915.50 & 739.500 & 1915.500 & $\begin{array}{c}- \\
1.851\end{array}$ & .064 \\
\hline Females & 40 & 50.01 & 2000.50 & & & & \\
\hline
\end{tabular}

Total 88

(Statistic is significant at 0.05):

$$
Z=z \text { value }
$$

The $\mathrm{Z}$ value is -1.851 with a p-value of .064 which is greater than the alpha value of 0.05 . This suggests that no significant differences existed in the views of male and female respondents with respect to the challenges the Assembly was faced with in the delivery of development projects in the district. In other words, the views of respondents on the challenges faced by the Assembly in development services in the district are the same irrespective of their different sex compositions.

\section{Implications for Development Communication}

This section presents the implications the key findings present for development communication. To start with, although the study revealed that there was stakeholder engagement prior to the delivery of projects, this engagement was very poorly done. The study further showed that ensuring effective stakeholder management was a challenge faced by the Assembly. Specifically, it was stated that stakeholders such as community members were not fully involved in the planning of development projects in the district. The DA largely relied on the representatives of the various stakeholders to send decisions taken by the Assembly to their various constituents. The Assembly's inability to tell whether information sent got to the intended audience indicates that information flow was not only inefficient but also one directional. This suggests that the one-way flow of communication still dominates the delivery of development services in Ghana. The one-directional flow of communication is simply about the Sender-Message-Channel-Receiver model whose limitation has been exposed by Mefalopulos (2008) on the basis that the target audience only becomes passive audience that receives the intended message without contributing anything meaningful to it. The weakness in the one-way communication flow has been further exposed by the overarching usefulness of the participatory communication model within development communication strategies.

To ensure increased stakeholder commitment in development activities, there is the need for dialogical, participative and horizontal communication in development service delivery (McAnany, 2012; Servaes, 2005). The participatory communication model when adopted ensures there is a democratisation and participation process which occurs at all levels including the national, regional and local all the way to the individual level (Salazar \& Hammer, 2008; Servaes, 2005).

Again, the study showed not much effort was made by the Assembly to define and communicate project goals to key stakeholders. Besides, though progress of the 
projects was monitored and communicated, there was poor communication between project contractors and the Assembly which poses a challenge to the effective management of development projects. More so, although reports were given at the various stages of the projects they were not done to the satisfaction of the selected stakeholders. Clearly, there were problems with communication throughout the design, planning and executing of development projects in the district. Indeed, the prevailing situation in the study area demonstrates that lack of communication complicates efforts to ensure common understanding among various development stakeholders. Of course, the situation may not be peculiar to the district. In support of this claim, Owusu (2014) observed that effective communication is not incorporated into development service delivery in Ghana. In essence, the seeming lack of concerted efforts to incorporate adequate communication strategies in the delivery of development services is at variance with the tenets of development communication. The potency of communication as a tool for promoting development service delivery cannot be contested.

The study seems to show a lack of clear efforts to incorporate communication techniques and models in the delivery of development projects in the district. This is very problematic and a huge challenge to the continuing relevance and popularity of development communication in Ghana. Development communication is seen as a social process, intentionally designed to seek a common understanding among all the participants of a development initiative, in a manner required to bring about development (FAO, 1984). Development communication is much more relevant to rural areas given the plethora of development problems faced by people in rural areas which calls for a shift in paradigms and trajectories in terms of development interventions (Mefalopulos, 2005; Odoom, 2020).

Finally, the study established that efforts to evaluate delivery of projects against their set goals were low coupled with the issue of low quality of some development projects executed in the district. Another concern has to do with delay in the completion of educational, health, roads, water, and sanitation projects initiated by the Assembly due to inadequate funds, low community support, and poor planning and poor monitoring. These findings prove that there was a clear lack of appreciation of the importance of creating a shared understanding about the development problems in the district and the measures to be adopted to improve the situation. If measures are not put in place to generate a common understanding among various stakeholders with respect to the delivery of development services, there will always be problems in the provision of development services. It is only when the citizens are aware of the intended benefits of development services that they will agree to help mobilize funds to ensure the completion of development projects. When community members are fully part of the planning, implementing and evaluating development projects, they tend to appreciate the value of their own efforts and the benefits they stand to gain and therefore, show more commitment in the process. It is against this backdrop that the inclusion of development communication ethos becomes apparent. Development 
communication ensures a change in the lives of people through active participation of all stakeholders in almost every stage of the development process. It also aims at creating a conducive environment and effecting positive social and behavior change (Centre for Development and Population Activities, 2000), and also generating community support and empowerment towards specific issues (Mefalopulos, 2008; Odoom, 2020) using vital communication tools and strategies.

\section{Conclusions}

The Assembly generally has some measures in place for the management of its development projects in the district. They include stakeholder management, involvement of project managers, defining project goals, assigning roles and responsibilities to key officers, as monitoring and evaluation of projects. However, there are concerns with the measures the Assembly has for managing its development projects. For instance, although there is stakeholder consultation prior to the delivery of projects, it is very ineffectively done. Indeed, ensuring effective stakeholder management is a challenge faced by the Assembly since not all the stakeholders are fully involved in the planning and execution of development projects in the district. Though community members are often invited to be part of the sod-cutting ceremonies of development, their overall involvement in planning and executing development projects in the district leaves much to be desired.

Again, there are problems with communication throughout the design, planning, execution and evaluation of development projects in the district. Also, efforts to evaluate development projects against their set goals are poor. The greatest challenge faced by the Assembly in its development efforts seems to be too much delay in completion of projects due to unhealthy politics, inadequate funds, low community support, poor planning and occasional changes in project designs. Besides, there is no significant difference in the views of male and female respondents with respect to the challenges the Assembly is faced with in the delivery of development projects in the district. The Assembly should look for other innovative means of mobilising revenue including the involvement of private sector and collaboration with corporate bodies in the district. The Local Government Service should effectively team up with the District Assembly to recruit more qualified project management personnel, and also provide adequate logistics to the Assembly so as to promote effective local development. Clear efforts should be made by the Assembly to incorporate effective communication techniques, methods, tools and strategies to enhance the delivery of development services in the district.

One main limitation of the study has to do with the fact that the total number (91) of respondents sampled for the study was considerably low. The sampling methods used limited the true picture of the quantitative aspect of the study. The researchers suggest that further studies be conducted using large sample sizes, and with more rigorous statistical tools for analysing the data. 


\section{References}

Ahenkan, A., Bawole, N., \& Domfer, K. (2013). Improving Citizens' Participation in Local Government Planning Financial Management in Ghana: A Stakeholder Analysisof the Sefwi Wiawso Municipal Assembly. Journal of Public Administration and Governance, pp. 191-208.

Ahwoi, K. (2006). Ghana's public administration reforms: Devolution, de-construction, delegation or decentralisation? Journal of Leadership, Management and Administration, $4(2), 8-43$.

Ahwoi, K. (2010). Local government and decentralisation in Ghana. Accra: Unimax Macmillan.

Asibuo, S. K. (2000). Decentralisation and capacity building in Ghana. Africa Insight, 29 $(3 / 4), 8-15$

Atakora, A. N. (2006). Decentralisation and effective revenue mobilisation: A case study of the Nkoranza District Assembly. Journal of Leadership, Management and Administration, 4 (2), 92-124.

Babbie, E. (2004). The practice of social science research (12 ${ }^{\text {th }}$ ed.). Wadsworth: Cengage Learning Inc.

Centre for Development and Population Activities (2000). Social mobilisation for reproductive health: A trainer's manual. Washington, D.C.

Damian, A. A. (2012). Managing the implementation of District Assembly Projects: Lessons from Atwima Nwabiagya. District. An unpublished MSc Dissertation, Kwame Nkrumah University of Science and Technology, Kumasi.

Diamond, L. (1999). Developing democracy: Toward consolidation. Baltimore: The John Hopkins University Press.

FAO. (1984). Expert Consultation on Communication for Development. FAO: Rome.

Falleti, T. G. (2005). 'A sequential theory of decentralisation: Latin American cases in comparative perspective'. American Political Science Review Journal, 99, pp. 3-17.

Gaventa, J. (2005). Reflections on the uses of the "Power Cube Approach" for analysing the spaces, places and dynamics of civil society participation and engagement. Prepared for Dutch CFA Evaluation 'Assessing Civil Society Participation as Supported In-Country by Cordaid, Hivos, Novib and Plan Netherlands.

Grindle, M. S. (2007). Going local: Decentralisation, democratisation, and the promise of good governance. Princeton \& Oxford: Princeton University Press.

Guest, G. (2013). Describing mixed methods research: An alternative to typologies. Journal of Mixed Methods Research, 7, 141-151.

Gyabaah, N. K. (2006). Democratic decentralisation, poverty reduction and sustainable development in Ghana: Challenges and opportunities. Journal of Leadership, Management and Administration, 4(2), 8-43.

Hilhorst, T., \& Guijt, I. (2006). Participatory Monitoring and Evaluation: A Process to Support Governance and Empowerment at the Local Level. Amsterdam, Netherlands: World Bank, Royal Tropical Institute, pp.1-60. 
Hoffman, B. D., \& Metzroth, M. K. (2010). The political economy of decentralisation in Ghana. Center for Democracy and Civil Society, Georgetown University. Paper prepared for the World Bank.

Hutchcroft, P. (2001). Centralisation and decentralisation in administration and politics: Assessing territorial dimensions of authority and power. Journal of Policy and Administration, 14 (1), 23-53.

Koranteng, R. O. (2006). The politics behind the decentralisation policies in Ghana. Journal of Leadership, Management and Administration, 4(2), 8-43.

Manor, J. (2011). Perspectives on decentralisation. Visby: Swedish International Centre for Local Democracy.

Martínez-Vázquez, J., \& Yao, M. (2009). Fiscal Decentralisation and Public Sector Employment. Public Finance Review, 37 (5). p. 539.

McAnany, E. G. (2012). Saving the World: A Brief History of Communication for Development and Social Change. Illinois: The University of Illinois.

Mefalopulos, P. (2008). Development communication sourcebook: broadening the boundaries of communication. Washington, D.C.: World Bank.

Mphande, F. A. (2016). Infectious diseases and rural livelihood in developing countries. Springer Science Business Media Singapore. Accessed 18 march 2018 from: DOI 10.1007/978-981-10-0428-5_2.

Odoom, D. (2020), Understanding Development Communication: A Review of Selected Literature. E-Journal of Humanities, Arts and Social Sciences, 1 (1), 37-48.

Odoom, D. (2016). Conceptualising decentralisation: Reflecting on some existing literature. Applied Research Journal, 1(4), 21-38.

Odoom, D. (2019). An Analysis of the Effectiveness of the Human Resource Arrangements within the Ghanaian Decentralised Government System: Views of Staff of Cape Coast Metropolitan Assembly. International Journal of Applied Research, 5(2), 25-32.

Odoom, D., Kyeremeh, C., \& Opoku, E. (2014). Human resource capacity needs at the District Assemblies: A study at Assin South District in Ghana. Journal of Sustainable Development, 7(5), 177-188.

Odoom, D., Mensah, F. M., Opoku, E., \& Acheampong, O. A. (2018). Sustaining development projects within the local government system of Ghana: Exploring the Views of Local Authorities and other Stakeholders in Shama District. International Journal of Innovative Research and Development, 7(12), 11-20.

Opoku, E., Kyeremeh, C., \& Odoom, D. (2014). Local Revenue Mobilisation Mechanisms: Evidence from the Abura-Asebu-Kwamankese District in Ghana. Journal of Developing Country Studies, 4(26), 255-266.

Owusu, E. (2014). The role of communication in sustaining development projects. The Case of Ejura Sekyedumase Municipality, Ghana. [Master Dissertation], KNUST.

Ribot, J. C. (2002). African decentralisation, local actors, powers and accountability. In UNRISD Programme on Democracy, Governance and Human Rights, Paper (8). 
Ribot, J. C. (2004). Waiting for democracy: The politics of choice in natural resource decentralisation. Washington, DC: World Research Institute.

Salazar, L., \& Hammer, C. (2008). Community Radio: Supporting Local Voices through Airwaves. In Paolo Mefalopulos (ed.), Development Communication Sourcebook. Washington: World Bank, p.180-194.

Sarantakos, S. (2005). Social research (3 ${ }^{\text {rd }}$ ed.). New York: Palgrave Macmillan.

Schoonenboom, J., \& Johnson, R. B. (2017). How to Construct a Mixed Methods Research Design. KZfSS Kölner Zeitschrift für Soziologie und Sozialpsychologie, 69(2), 107-131.

Servaes, J. (2005). Participatory communication: The new paradigm? In: Hemer, O. (ed.) Media and Global Change: Rethinking Communication for Development. Buenos Aires: CLACSO - Consejo Latinoamericano de Ciencias Sociales, pp.91-103.

Shuttleworth, M. (2013). Research Design. Available at: http://explorable.com/descriptive-research-design

Simanowitz, A. (2004). Issues in designing effective Microfinance impact assessment systems. Working Paper No. 8. Retrieved from: http://www.ids.ac.uk/impact/Publications/publications workingpapers.html

Stanton, A. (2009). Decentralisation and municipalities in South Africa: An analysis of the mandate to deliver basic services. Unpublished thesis, University of KwaZuluNatal.

Tettey, W. J. (2006). Deepening decentralisation: Is Ghana ready for subsidiarity? Accra: Centre for Democratic Development-Ghana.

Wood, S. N. (2000). Building the human resources capacity of district Assemblies. Koforidua: MLGRD. 